\title{
PENERAPAN STRATEGI CATALISTING UNTUK MENINGKATKAN KEMAMPUAN MENULIS ESAI
}

\author{
Setyawan Pujiono \\ Fakultas Bahasa dan Seni Universitas Negeri Yogyakarta \\ e-mail: setya_one14@yahoo.com
}

\begin{abstract}
This study aims to improve students' essay writing skills at the stages of content development, organization, and essay development using the catalisting strategy. This was an action research study involving the students of Class A of JPBSI FBS UNY enrolled in 2009 attending the Factual Writing course. The data were collected through observations, interviews, and documents. The instruments included a field note guide, an interview guide, a scoring rubric, and a questionnaire. The results showed that there was an improvement of the students' skills in developing contents, organizing problems, and developing the essay. In the problem organization, the students were capable of finding new problems and organizing them in a logical essay outline. In the essay development, they managed to develop the essay in a logical sequence of problems and effective sentences with few errors in spelling and punctuation.
\end{abstract}

Keywords: learning of writing, learning strategy, essay writing

\section{PENDAHULUAN}

Menulis merupakan salah satu matakuliah wajib di Jurusan Pendidikan Bahasa dan Sastra Indonesia (JPBSI) Fakultas Bahasa dan Seni (FBS) Universitas Negeri Yogyakarta (UNY). Mata kuliah ini bertujuan agar mahasiswa memiliki pengetahuan, wawasan, dan kemampuan tentang menulis laporan, prosedur, esai argumentatif, recount, dan eksposisi. Dengan kompetensi itu, mahasiswa diharapkan dapat berkomunikasi tulis dengan baik.

Menulis adalah suatu proses penuangan ide dalam bentuk simbolsimbol bahasa (Nurhadi, 2009). Menulis merupakan aktivitas berpikir yang diwujudkan dalam susunan huruf-huruf yang mempunyai makna. Isi tulisan akan mencirikan kepribadian penulis sesuai dengan bahasa yang dikuasai. Secara umum, bahasa yang dipakai sesuai dengan tujuan dan karakter penulisnya.
Ketika menulis, mahasiswa perlu merumuskan ragam tulisan yang akan dikembangkan. Mahasiswa harus menyesuaikan ragam (genre) tulisan agar gagasan dan pesannya sampai kepada pembaca. Oleh karena itu, mahasiswa perlu merumuskan tujuan dan sasaran pembaca sebelum mengembangkan karangannya.

Sebagai bagian dari keterampilan berbahasa, keterampilan menulis mempunyai kedudukan yang sangat penting dan strategis karena melalui menulis esai mahasiswa dapat mengungkapkan gagasan dan masalah pada orang lain. Selain itu, melalui karangan esai, mahasiswa dapat menuangkan masalah dengan menggunakan bahasa yang baik dan runtut untuk dasar menulis karya ilmiah. Artinya, pemilihan kajian menulis esai ini diangkat untuk membekali mahasiswa mampu menulis berbagai karya tulis ilmiah yang lain. 
Agar aktivitas menulis esai menjadi lebih aktif, kreatif, dan menyenangkan, dosen perlu mengetahui beberapa hal penting. Pertama, dosen harus jeli dalam menentukan materi perkuliahan, penentuan alokasi waktu, dan penentuan sumber bahan perkuliahan. Kedua, dosen harus mempunyai kemampuan, strategi, dan kreativitas mengajar yang baik. Ketiga, peran dosen adalah pelaku pengajaran, sedangkan mahasiswa pelaku belajar. Oleh sebab itu, dosen yang memegang peranan di kelas disorot sebagai penyebab kegagalan mahasiswa menguasai pengetahuan, keterampilan, dan keahlian tertentu.

Tujuan perkuliahan menulis esai adalah memperoleh pengetahuan, wawasan, dan kemampuan penulisan. Akan tetapi, tujuan perkuliahan tesebut tidak mudah untuk dicapai. Dalam proses perkuliahan, ditemukan banyak permasalahan. Permasalahan itu berupa kesulitan menemukan ide, kesulitan menuangkan gagasan, kesalahan bahasa, dan kurangnya motivasi belajar mahasiswa. Kesulitan-kesulitan tersebut, jika tidak segera diatasi akan mengakibatkan kendala berkelanjutan dalam proses perkuliahan. Jika identifikasi kesulitan belajar mahasiswa belum dilakukan secara tepat, dikhawatirkan terjadi ketidaktepatan dalam pemilihan strategi perkuliahan. Ketidaktepatan penggunaan strategi pembelajaran dapat mengakibatkan tidak tercapainya tujuan perkuliahan menulis esai.

Berdasarkan studi pendahuluan, perkuliahan menulis esai mahasiswa JPBSI FBS UNY belum memuaskan. Hasil observasi dan wawancara ditemukan beberapa masalah dalam perkuliahan menulis esai. Masalah pertama adalah dari sisi metode/strategi. Metode yang digunakan dosen hanya mengajarkan teori menulis esai. Selanjutnya, mahasiswa diminta untuk menulis esai dengan tema yang ditentukan kemudian dikumpulkan tanpa ada tindak lanjutnya. Metode pembelajaran tersebut, hanya mengajarkan teori menulis esai tanpa mengajak mahasiswa untuk mengembangkan ide, mengidentifikasi kesalahan, dan penyuntingan. Dosen dalam proses menulis masih sangat dominan, sehingga mahasiswa belum berkembang sesuai dengan pengetahuannya.

Ketika menulis, mahasiswa belum melakukan pengembangan masalah dan upaya perbaikan kesalahan tulisannya, misalnya dalam bentuk pemetaan gagasan, menuangkan gagasan, dan penyuntingan. Akibatnya, mahasiswa kesulitan ketika menulis, sehingga mereka cenderung melakukan plagiat/menjiplak karya orang lain. Mahasiswa merasa kegiatan menulis adalah aktivitas yang kurang penting.

Masalah berikutnya adalah penilaian dosen hanya pada hasil bukan pada proses. Dosen menilai karya tulis mahasiswa pada unsur kuantitas saja. Karya tulis mahasiswa setelah dinilai dosen tidak dikembalikan, sehingga mereka tidak mengetahui letak kesalahan dan upaya perbaikannya. Dosen tidak melakukan penilaian proses. Padahal, penilaian proses sebaiknya dilakukan dosen dengan melibatkan langsung mahasiswa saat berdiskusi kelompok, penyuntingan, dan evaluasi atau refleksi. Masalah-masalah tersebut yang mengakibatkan kreativitas mahasiswa menjadi terhambat, sehingga kemampuan menulis esai mahasiswa menjadi kurang baik.

Dosen memerlukan inovasi dan strategi untuk mengatasi berbagai masalah dalam perkuliahan menulis esai. Untuk itu, penelitian ini akan melakukan inovasi terhadap pembelajaran menulis esai yang dinilai belum maksimal. Upaya tersebut adalah meningkatkan kualitas pembelajaran menulis esai menggunakan strategi Catalisting. Penelitian ini dilakukan untuk meningkat- 
kan kemampuan mahasiswa agar lebih fokus dan kreatif dalam menulis esai.

Penerapan strategi Catalisting bertujuan untuk meningkatkan dan memperbaiki proses menulis esai sehingga mahasiswa benar-benar mampu mengembangkan subtansi isi, mengorganisasi karangan, dan mengembangkan tulisan. Penggunaan strategi Catalisting relevan dengan kegiatan menulis karena strategi ini meliputi empat tahapan yang kreatif. Tahapan tersebut adalah membaca esai model (bacalah), menyusun kerangka karangan (tatalah), mengembangkan karangan (tulislah), dan menyunting karangan (suntinglah). Penerapan strategi Catalisting memungkinkan mahasiswa untuk menguatkan dan menerapkan keterampilan yang mereka peroleh dari berbagai matakuliah. Mahasiswa dilatih untuk dapat memecahkan masalah yang mereka hadapi dalam segala situasi. Penggunaan strategi Catalisting untuk melatih mahasiswa terampil menulis esai berdasarkan temuan masalah dalam esai model.

Strategi Catalisting terinspirasi dari dasar pemikiran pendekatan proses. Dalam pendekatan proses menulis terdiri atas pramenulis, membuat draft, menyunting, merevisi, dan mempublikasikan. Berlandaskan lima tahapan tersebut strategi Catalisting dirancang agar pembelajaran menulis menjadi lebih kreatif dan menyenangkan.

Proses menulis esai membutuhkan latihan yang tekun dan terus-menerus. Ketekunan ini menjadi penting, ketika penulis sadar bahwa kemampuan berbahasa erat kaitannya dengan kemampuan berpikirnya. Bahasa mencerminkan pola pikir seseorang. Jadi, semakin terampil berpikir, makin jernih pula jalan pikirannya, dan semakin jelas pula ia menulis (Wibowo, 2007:111). Pada umumnya, mahasiswa yang mempunyai nilai kompetensi tinggi, akan tinggi pula nilai keterampi- lan menulisnya. Oleh karena itu, baik tidaknya kompetensi pembelajar, pada umumnya mencerminkan keterampilan berbahasanya (Nurgiyantoro, 2001).

Keterampilan menulis esai akan tercapai jika dosen menerapkan strategi pembelajaran yang tepat sasaran. Penerapan strategi tersebut disesuaikan dengan kondisi, budaya, dan karakter mahasiswa. Berdasarkan masalah di atas, penelitian berjudul Penggunaan Strategi Catalisting untuk Meningkatkan Kemampuan Menulis Esai Mahasiswa Jurusan Pendidikan Bahasa dan Sastra Indonesia Fakultas Bahasa dan Seni Universitas Negeri Yogyakarta ini dilaksanakan.

Permasalahan penelitian ini adalah bagaimanakah meningkatkan kemampuan menulis esai mahasiswa JPBSI FBS UNY melalui strategi Catalisting? Secara khusus penelitian ini bertujuan untuk; (1) meningkatkan kemampuan menulis esai pada bagian isi, (2) meningkatkan kemampuan menulis esai pada organisasi karangan, dan (3) meningkatkan kemampuan menulis esai pada bagian bahasa.

\section{METODE}

Penelitian ini menggunakan ancangan kualitatif. Penggunaan ancangan kualitatif akan menghasilkan data-data verbal dan nonverbal. Data verbal dan nonverbal diperoleh dari subjek dan atau perilaku yang diamati dalam situasi alamiah. Data verbal terdiri atas hasil wawancara, hasil observasi, tuturan dosen dan mahasiswa ketika perkuliahan, perencanaan perkuliahan, proses dan hasil perkuliahan menulis esai. Sementara itu, data-data nonverbal berwujud foto-foto dalam kegiatan perkuliahan menulis esai menggunakan strategi Catalisting.

Data penelitian ini diperoleh dari mahasiswa dan perilaku yang diamati saat perkuliahan di kelas A semester III JPBSI FBS UNY. Pengambilan data pene- 
litian dilakukan di ruang laboratorium bahasa JPBSI FBS UNY ketika perkuliahan dilaksanakan. Data penelitian diambil selama 6 bulan dari bulan Juli sampai dengan Desember 2010 dari sebelum tindakan sampai akhir tindakan.

Data-data tersebut dikumpulkan peneliti melalui pengamatan dari sebelum tindakan, ketika tindakan, dan akhir tindakan. Data-data yang terkumpul bersifat alamiah sesuai kenyataan di lapangan. Selanjutnya, semua data yang terkumpul dikelompokkan sesuai dengan tujuan dan permasalahan yang diteliti kemudian dianalisis secara induktif. Analisis data menggunakan pendekatan kualitatif, tanpa menggunakan perhitungan statistik. Setelah itu, hasil data ditafsirkan, divalidasi, dicek keabsahannya, dan dideskripsikan.

Berdasarkan jenisnya, penelitian ini termasuk dalam Penelitian Tindakan Kelas (Classroom Action Research). Penelitian ini menggunakan desain PTK model Kemmis dan McTaggart. Ada tiga komponen yang dikenalkan dalam penelitian tindakan, yaitu (a) perencanaan (planning), (b) pelaksanaan tindakan sekaligus observasi (observing), dan (c) refleksi (reflecting). Hubungan dari ketiga komponen tersebut dimaknai menjadi satu siklus. Penelitian tindakan ini membuat gambaran secara jelas mengenai suatu hal, menentukan prediksi, mendapatkan makna, dan implikasi dari suatu masalah yang ingin diselesaikan.

Dalam aktivitasnya, peneliti terlibat langsung dalam setiap tahapan bersama dosen Matakuliah Menulis. Tahapan tersebut dimulai dari perencanaan, pelaksanaan, pengamatan, dan refleksi. Apabila peneliti sudah mengetahui keberhasilan dan hambatan tindakan pada siklus pertama, maka peneliti dan kolabulator merancang tindakan siklus kedua. Kegiatan pada siklus kedua merupakan perbaikan pada siklus pertama disertai dengan pelbagai perbaikan dari kelemahan yang telah dilakukan.

Teknik pengumpulan data yang digunakan dalam penelitian ini berupa hasil pengamatan, wawancara, dan dokumentasi. Selain itu, data diperoleh dari tugas menulis esai mahasiswa kelas A JPBSI FBS UNY.

Analisis data dilakukan melalui tiga tahapan, yaitu mereduksi data, penyajian data, dan pengambilan kesimpulan. Reduksi data dilakukan dengan cara merekam, menafsirkan, dan menyeleksi (mengategorisasi) data penelitian yang berkaitan dengan fokus masalah. Penyajian data yaitu memberikan gambaran yang mengarah pada pemerolehan jawaban atas masalah penelitian. Penyajian data dikelompokkan berdasarkan fokus penelitian. Pengambilan simpulan menggambarkan hasil penelitian secara menyeluruh tentang sesuatu yang diteliti secara apa adanya. Peneliti menginterpretasi data untuk menghasilkan temuan.

Data penelitian dianalisis secara kualitatif. Keabsahan data dilakukan dengan trianggulasi (pengamatan, wawancara, dan dokumentasi). Agar tercapai reliabilitas data dilakukan diskusi antar peneliti, antar dosen (intraratter), dan dengan dosen yang terlibat. Validitas data diperoleh pada saat perencanaan, proses, dan hasil evaluasi.

Kriteria keberhasilan yang berkaitan dengan kemampuan menulis esai (aspek isi, organisasi, dan kebahasaan) ialah berdasarkan hasil pembelajaran menulis esai, dari segi proses dikatakan berhasil, jika mencapai target minimal ketuntasan sebesar $63 \%-81 \%$. Sementara itu, dari segi produk, mahasiswa dikatakan mampu menulis esai, jika mencapai nilai 71. Hal ini disebabkan oleh Standar Ketuntasan Belajar Minimal (SKBM) mahasiswa JPBSI FBS UNY adalah 71. 


\section{HASIL DAN PEMBAHASAN}

Pembahasan hasil penelitian meliputi proses dan hasil pembelajaran menulis esai melalui strategi Catalisting yang terdiri atas tiga tahap, yaitu (1) tahap mengembangkan subtansi isi, (2) tahap mengorganisasi karangan, dan (3) tahap mengembangkan tulisan. Pada setiap tahapan dibahas tentang kelebihan dan hambatan-hambatan yang dihadapi dosen dan mahasiswa di dalam aktivitas perkuliahan. Berikut ini pembahasan hasil peningkatan kemampuan menulis esai dengan strategi Catalisting.

\section{Tahap Mengembangkan Subtansi Isi}

Pada tahap mengembangkan subtansi isi, kegiatan yang dilakukan adalah membaca esai model, menentukan keluasan tesis, dan mengembangkan masalah. Hasil akhir pada tahap membaca esai model, dosen sudah menyampaikan tujuan membaca esai. Mahasiswa, serius membaca esai model yang diberikan dosen. Ketika membaca esai model, mahasiswa fokus untuk menemukan judul, tesis, konteks, masalah, dan solusinya. Hasil temuan tersebut kemudian ditulis dalam bentuk kalimatkalimat kunci.

Pada tahap mengembangkan tesis, mahasiswa diminta untuk memahami terlebih dahulu pengertian tesis. Dosen menjelaskan pengertian tesis dan memberikan contoh kalimat yang memuat tesis. Tesis merupakan pernyataan inti yang muncul di paragraf awal sebuah karangan esai. Oleh karena itu, mahasiswa ditekankan untuk mengetahui inti masalah yang akan dikembangkan dalam karangannya.

Pada tahap mengembangkan masalah, dosen meminta mahasiswa untuk menyusun kerangka karangan berdasarkan masalah-masalah dari temuan esai model, pengalaman, dan pengetahuan masing-masing. Dosen meminta mahasiswa untuk fokus pada pengembangan masalah dan solusi esai. Selain itu, dosen meminta mahasiswa untuk membaca esai lain yang berkaitan dengan topik yang dikembangkan. Masalah-masalah yang ditemukan dapat dijadikan inspirasi untuk mengembangkan karangannya.

Berdasarkan penilaian proses, aktivitas dosen dan mahasiswa pada tahap mengembangkan masalah dan solusi di atas berkategori baik. Artinya, dosen mampu mengarahkan mahasiswa untuk mengembangkan subtansi isi esai dari judul, tesis, masalah, dan solusinya. Saat perkuliahan, interaksi dosen dan mahasiswa sudah berjalan dengan interaktif. Mahasiswa tidak canggung bertanya atau berdiskusi dengan dosen jika mengalami kesulitan saat perkuliahan. Sebaliknya, dosen akan memberikan komentar terhadap hasil tulisan mahasiswa dan berinteraksi dengan setiap mahasiswa.

Untuk penilaian hasil, dapat diketahui bahwa dari 23 mahasiswa, 10 mahasiswa mendapatkan skor 4 dan 13 mahasiswa mendapatkan skor 3. Jika dipersentasekan dengan 23 mahasiswa yang mengikuti pembelajaran siklus 2, maka 43\% mahasiswa mendapatkan skor 4 dan 57\% mahasiswa mendapatkan skor 3. Hal ini berarti, semua mahasiswa mampu menulis esai berdasarkan hasil pengembangan masalah dan solusi dengan baik.

Kesalahan yang paling banyak dilakukan mahasiswa adalah urutan masalah dalam karangan. Hal yang menyebabkan urutan masalah tidak logis karena mahasiswa belum memperhatikan tingkat kepentingan masalah yang ditulis. Selain itu, saat perkuliahan dosen belum memberikan contoh cara mengurutkan masalah secara logis. Konsentrasi mahasiswa hanya berpusat pada pengembangan tulisan. Akibatnya, masalah yang dikembangkan dalam karangan belum runtut, meskipun 
tidak mempengaruhi isi karangan.

Berdasarkan hasil refleksi terhadap pelaksanaan perkuliahan tahap mengembangkan subtansi isi, diketahui bahwa dari segi proses, aktivitas mahasiswa dalam perkuliahan sudah sesuai dengan yang diharapkan. Mahasiswa antusias membaca esai model untuk menemukan bagian-bagian esai, merumuskan masalah, menggali masalahmasalah baru, dan menyusunnya dalam kerangka karangan.

Berdasarkan hasil refleksi, dari segi hasil, perkuliahan sudah sesuai dengan yang diharapkan. Hal ini disebabkan oleh dari 23 mahasiswa, yang mengikuti pembelajaran, $43 \%$ mahasiswa mendapatkan skor 4 dan 57\% mahasiswa mendapatkan skor 3. Berdasarkan hasil penilaian dan wawancara dengan mahasiswa, pada umumnya mereka sudah mampu menemukan subtansi isi (tesis, konteks, masalah, dan solusi), mengembangkan masalah dan solusi, namun tidak menuliskannya secara lengkap.

Mahasiswa pada tahap mengembangkan subtansi isi mengalami beberapa kemudahan. Kemudahan-kemudahan yang dialami mahasiswa pada tahap mengembangkan subtansi isi menggunakan strategi Catalisting adalah sebagai berikut.

1) Mahasiswa mudah menemukan subtansi isi (judul, tesis, konteks, masalah, solusi, dan simpulan) sebuah karangan esai. Selain itu, mahasiswa dapat memahami kalimat atau penyataan yang memuat bagian-bagian isi tersebut.

2) Mahasiswa lebih mudah memperoleh judul/topik untuk menulis esai baru. Berdasarkan temuan masalah dalam esai model, mahasiswa lebih mudah merumuskan judul baru untuk karangannya. Selain itu, pemilihan judul lebih variatif, aktual, dan menarik dibandingkan dengan hasil karangan sebelum tindakan dilakukan.

3) Mahasiswa mudah menentukan dan mengembangkan masalah-masalah baru untuk bahan menulis esai. Hal tersebut dikarenakan mahasiswa sudah menemukan, mendiskusikan, dan mempresentasikan temuan masalah dalam esai model yang dibaca. Kegiatan di atas sangat penting untuk menunjang pengembangan tesis, masalah, dan solusi saat mengarang.

4) Mahasiswa mudah mengembangkan tesis, menentukan masalah-masalah inti, dan mengembangkan masalah pendukung (suport) dalam karangannya. Masalah-masalah yang dikembangkan diarahkan pada suatu hal yang dikuasai oleh mahasiswa, sehingga pengembangan masalah menjadi lebih tuntas.

\section{Tahap Mengorganisasi Karangan}

Pada tahap mengorganisasi karangan, dilakukan melalui empat tahap kegiatan. Keempat tahap kegiatan tersebut, yaitu (1) mahasiswa menuliskan hasil temuan dari esai model, (2) mahasiswa mengembangkan masalah dan solusi, (3) mahasiswa dibimbing dengan pertanyaan-pertanyaan, dan (4) menyusun kerangka karangan dengan memperhatikan komposisinya.

Kegiatan pertama adalah mahasiswa menuliskan hasil temuan dari esai model yang dibaca. Berdasarkan hasil catatan lapangan, sebagian besar mahasiswa sudah dapat menemukan bagianbagian isi (judul, general statement, tesis, masalah, dan solusi) dalam esai model dengan baik. Semua mahasiswa dapat menemukan judul, tesis, masalah, dan solusi dalam esai model yang dibaca.

Kegiatan kedua adalah mahasiswa mengembangkan masalah dan solusi. Mahasiswa mengembangkan masalah dan solusi berdasarkan hasil temuan membaca esai model. Selain itu, 
pengembangan masalah juga diperoleh berdasarkan hasil pengalaman mahasiswa. Masalah-masalah yang ditemukan dari esai model dikreasikan untuk dijadikan masalah baru dalam karangannya.

Kegiatan ketiga adalah mahasiswa menjawab pertanyaan-pertanyaan panduan. Berdasarkan hasil catatan lapangan, pada tahap ini, ada beberapa mahasiswa yang kesulitan mengembangkan masalah inti dan masalah-masalah pendukungnya (suport). Oleh karena itu, mahasiswa menjawab pertanyaan-pertanyaan dari dosen agar dapat mengembangkan masalah-masalahnya

Kegiatan kelima adalah menyusun kerangka karangan dengan memperhatikan komposisinya. Tujuannya agar mahasiswa dapat menata masalahmasalah dan solusi yang telah dikembangkan dalam kerangka karangan secara runtut. Mahasiswa menuangkan masalah-masalah yang dikembangkan dalam bentuk kalimat-kalimat kunci. Dosen juga sudah memberikan contoh mengorganisasi masalah dalam kerangka karangan menggunakan kalimatkalimat kunci.

Berdasarkan penilaian proses, aktivitas mahasiswa pada tahap mengorganisasi karangan berkategori baik. Hal ini berarti, mahasiswa kreatif mengembangkan masalah dan solusi berdasarkan esai model dan pengalamannya masing-masing. Selain itu, mahasiswa mampu mengembangkan masalah dan solusi berdasarkan temuan dalam esai model dan pengalamannya. Mahasiswa dapat menyusun kerangka karangan dengan baik berdasarkan pengembangan masalah tersebut.

Pelaksanaan perkuliahan pada tahap mengorganisasi karangan sudah berjalan sesuai dengan yang diharapkan. Hal ini dibuktikan oleh dari 23 mahasiswa yang mengikuti pembelajaran siklus 2, 43\% mahasiswa mendapatkan skor 4 dan 57\% mahasiswa mendapatkan skor 3. Pada umumnya, organisasi masalah dalam karangan mahasiswa sudah baik, sehingga hampir semuanya mendapatkan skor 3 .

Mahasiswa mengalami beberapa kemudahan dalam mengorganisasi karangan menggunakan strategi Catalisting. Kemudahan-kemudahan yang dialami mahasiswa pada tahap mengorganisasi karangan adalah sebagai berikut.

1) Mahasiswa mampu mengonstruksi pengetahuannyasaatmengorganisasi karangan. Langkah-langkahnya adalah (1) pengetahuan dan keterampilan mahasiswa diperoleh dari proses menemukan sendiri, (2) pengetahuan dan keterampilan mahasiswa diperoleh dengan konteks yang terbatas, sesuai dengan kompetensi yang dicapai, yaitu keterampilan menulis esai berdasarkan pengembangan masalah, (3) Dalam pembelajaran terdapat kegiatan menemukan, yaitu menemukan topik yang menarik dan menemukan masalah-masalah yang dikembangkan dalam karangannya.

2) Mahasiswa mampu menyusun kerangka karangan dengan baik. Artinya, urutan masalah di dalam kerangka karangan disusun dengan logis. Masalah-masalah dituangkan dalam bentuk kalimat-kalimat kunci di dalam kerangka karangan. Kalimat-kalimat kunci itulah yang akan dikembangkan menjadi paragraf-paragraf dalam tubuh karangan pada tahap menulis selanjutnya.

3) Mahasiswa mengetahui dan memahami komposisi sebuah karangan esai (pembuka, tubuh, dan penutup). Pengetahuan dan pemahaman komposisi karangan oleh mahasiswa mempengaruhi kemampuan penyajian masalah dalam karangannya. Oleh karena itu, mahasiswa sangat kreatif memaparkan masalah-masalah dan 
solusi di dalam karangannya, sehingga mudah dipahami pembaca.

\section{Tahap Mengembangkan Tulisan}

Pada tahap ini ada dua kegiatan yang dilakukan mahasiswa, yaitu (1) menulis esai versi sendiri menggunakan kata, kalimat, paragraf, ejaan, dan tanda baca yang benar dan (2) menyunting sekaligus memperbaiki hasil karangannya.

Pada tahap mengembangkan karangan, mahasiswa menulis esai berdasarkan kerangka karangan yang telah disusunnya. Mahasiswa memulai menulis dari bagian awal, tubuh, dan akhir karangan. Akan tetapi, sebelum menulis dosen memberikan contoh menulis kalimat dan paragraf pada bagian awal, tubuh, dan akhir karangan. Kemudian, dosen mengarahkan mahasiswa untuk menulis esai dimulai dari judul, tesis, masalah, dan solusi.

Pada tahap penyuntingan, mahasiswa melakukan penyuntingan dan perbaikan pada karangannya. Mahasiswa melakukan penyuntingan dengan tiga kegiatan, yaitu self editing, peer editing, dan klarifikasi. Penyuntingan dilakukan pada tiga aspek yaitu penyuntingan isi, penyuntingan organisasi, dan penyuntingan bahasa. Akan tetapi, dalam subab ini yang akan diuraikan adalah proses penyuntingan aspek kebahasaan.

Sementara itu, dari aktivitas mahasiswa, pelaksanaan pembelajaran tahap pada mengembangkan tulisan, diketahui bahwa dari segi proses perkuliahan sudah sesuai dengan yang diharapkan. (1) Secara umum mahasiswa tidak kesulitan menyusun kalimat, paragraf dengan menggunakan ejaan dan tanda baca yang baik. (2) Mahasiswa ketika menyunting karangan mampu menentukan susunan kalimat, paragraf, ejaan, dan tanda baca yang salah. (3) Mahasiswa dapat memperbaiki kesalahan bahasa yang dilakukan dalam karangannya.

Dalam pelaksanaannya, pada tahap mengembangkan tulisan dan penyuntingan dengan strategi Catalisting diperoleh beberapa keunggulan. Adapun keunggulan-keunggulan tersebut adalah sebagai berikut.

1) Mahasiswa mampu mengarang esai dengan pilihan kata, kalimat, dan paragraf yang efektif. Kemampuan mahasiswa menulis esai tampak pada susunan kalimat dan paragraf yang sesuai dengan kaidah teori penulisan. Selain itu, gagasan dan masalah yang disampaikan melalui karangannya mudah dipahami pembaca. Masalah-masalah yang disajikan runtut sesuai dengan subtansi isi sebuah karangan esai.

2) Mahasiswa mampu melakukan proses penyuntingan pada subtansi isi, organisasi, dan bahasa. Kemampuan mahasiswa menyunting subtansi isi dapat dilihat dari kelengkapan dan komposisi karangan esai (judul, tesis, masalah, solusi, dan simpulan). Berikutnya, kemampuan mahasiswa menyunting organisasi tulisan dapat dilihat dari organisasi dan urutan masalah dalam karangan. Kemampuan mahasiswa menyunting aspek kebahasaan dapat dilihat dari diksi, kalimat, paragraf, tata bahasa, ejaan, dan tanda baca.

Tingkat kemampuan mahasiswa menulis esai menggunakan strategi $\mathrm{Ca}$ talisting pada siklus 2 disajikan lengkap dengan nilai dan kualifikasinya pada tabel 2. 
Tabel 1.1 Kemampuan Menulis Esai

\begin{tabular}{|c|c|c|c|c|c|c|c|c|c|}
\hline \multirow[t]{3}{*}{ No. } & \multirow[t]{3}{*}{ Nama } & \multicolumn{5}{|c|}{ Aspek yang Dinilai } & \multirow{3}{*}{$\begin{array}{l}\text { Jumlah } \\
\text { Skor }\end{array}$} & \multirow[t]{3}{*}{ Nilai } & \multirow{3}{*}{$\begin{array}{c}\text { Kualifi } \\
\text { kasi }\end{array}$} \\
\hline & & \multirow[t]{2}{*}{ Isi } & \multirow[t]{2}{*}{ Org } & \multirow{2}{*}{\multicolumn{2}{|c|}{$\begin{array}{lc} & \text { Bahasa } \\
\text { Kt \& } & \text { Prg } \\
\text { Klmt } & \& \\
& \text { Mkn } \\
\end{array}$}} & \multirow[b]{2}{*}{$\begin{array}{c}\text { Ejn \& } \\
\mathrm{Tb}\end{array}$} & & & \\
\hline & & & & & & & & & \\
\hline & Kelompok tinggi & & & & & & & & \\
\hline 1. & Kristin Fuad Fourina & 4 & 4 & 3 & 4 & 3 & 18 & 90 & $\mathrm{~L}$ \\
\hline 2. & Aprilina Zulia M & 4 & 4 & 3 & 3 & 4 & 18 & 90 & $\mathrm{~L}$ \\
\hline 3. & Retno Wulan Sari & 4 & 3 & 3 & 4 & 4 & 18 & 90 & $\mathrm{~L}$ \\
\hline 4. & Gita Atmania Dewi & 3 & 3 & 3 & 3 & 3 & 15 & 75 & $\mathrm{~L}$ \\
\hline 5. & Eka Yunia Wardani & 4 & 3 & 3 & 4 & 3 & 17 & 85 & $\mathrm{~L}$ \\
\hline 6. & Nur Kurniasih & 3 & 3 & 3 & 3 & 4 & 16 & 80 & $\mathrm{~L}$ \\
\hline 7. & Novella Cathlin & 4 & 4 & 3 & 3 & 4 & 18 & 90 & $\mathrm{~L}$ \\
\hline 8. & $\begin{array}{l}\text { Alinda } \\
\text { Kelompok sedang }\end{array}$ & 3 & 3 & 3 & 3 & 4 & 16 & 80 & $\mathrm{~L}$ \\
\hline 1. & Endah Kusminarti & 3 & 3 & 3 & 3 & 4 & 16 & 80 & $\mathrm{~L}$ \\
\hline 2. & Yurista Anggayasti & 3 & 4 & 3 & 4 & 3 & 17 & 85 & $\mathrm{~L}$ \\
\hline 3. & Muhammad Catur JP & 4 & 4 & 3 & 3 & 3 & 17 & 85 & $\mathrm{~L}$ \\
\hline 4. & Maimunah & 3 & 3 & 3 & 3 & 3 & 15 & 75 & $\mathrm{~L}$ \\
\hline 5. & Anis Rahmawati & 4 & 4 & 3 & 3 & 3 & 17 & 85 & $\mathrm{~L}$ \\
\hline 6. & Linda Triyantika & 3 & 4 & 4 & 4 & 3 & 18 & 90 & $\mathrm{~L}$ \\
\hline 7. & Eka Supriyanto & 4 & 4 & 3 & 3 & 3 & 17 & 85 & $\mathrm{~L}$ \\
\hline 8. & $\begin{array}{l}\text { Winda Prastika Sari } \\
\text { Kelompok rendah }\end{array}$ & 3 & 4 & 3 & 4 & 3 & 17 & 85 & $\mathrm{~L}$ \\
\hline 1. & Alfika Rachmah M & 3 & 3 & 3 & 3 & 3 & 15 & 75 & $\mathrm{~L}$ \\
\hline 2. & Joko Prayitno & 3 & 3 & 3 & 3 & 3 & 15 & 75 & $\mathrm{~L}$ \\
\hline 3. & Nur Azizah & 3 & 3 & 2 & 3 & 4 & 15 & 75 & $\mathrm{~L}$ \\
\hline 4. & Yuliastanti & 4 & 3 & 2 & 3 & 4 & 16 & 80 & $\mathrm{~L}$ \\
\hline 5. & Robiul Mariroh & 4 & 4 & 3 & 4 & 3 & 18 & 90 & $\mathrm{~L}$ \\
\hline 6. & Gilang Yan Aditiya & 3 & 3 & 3 & 3 & 3 & 15 & 75 & $\mathrm{~L}$ \\
\hline 7. & Fandi Kurniawan & 3 & 3 & 2 & 3 & 4 & 15 & 75 & $\mathrm{~L}$ \\
\hline Rata & rata & & & & & & & 82,39 & \\
\hline
\end{tabular}

Sejumlah 23 mahasiswa yang mengikuti perkuliahan, semuanya $(100 \%)$ dinyatakan lulus. Mahasiswa dinyatakan lulus karena nilai yang diperoleh di atas standar kelulusan yaitu $>70$. Maka, dengan melihat hasil siklus 2 tersebut, perkuliahan menulis esai dengan strategi Catalisting sudah berhasil.

\section{SIMPULAN}

Strategi Catalisting terbukti efektif dapat meningkatkan kemampuan menulis esai. Penerapan strategi Catalisting terbukti berpengaruh lebih baik terhadap hasil kemampuan mahasiswa menulis esai dibandingkan dengan sebelum dikenai tindakan. Hal ini dibuktikan adanya peningkatan skor nilai rerata pretest dengan nilai rerata postest (siklus 2) sebesar 21,67 . Peningkatan kemampuan menulis esai mahasiswa JPBSI FBS UNY secara khusus dapat disimpulkan dari tiga tahap kegiatan, yaitu mengembangkan subtansi isi, mengorganisasi masalah, dan mengembangkan tulisan. Berikut ini simpulan dari aspek-aspek tersebut. 
Tahap mengembangkan subtansi isi dilakukan melalui kegiatan membaca esai model, mengembangkan tesis, dan mengembangkan masalah. Strategi Catalisting terbukti efektif dapat meningkatkan kemampuan mengembangkan subtansi isi karangan. Peningkatan kemampuan mengembangkan subtansi isi dapat terwujud karena dosen dan mahasiswa mengikuti prosedur pelaksanakan tindakan sesuai dengan rancangan pembelajaran yang telah disusun. Mahasiswa mampu menemukan subtansi isi, mengembangkan aspek-aspek utama, dan mengembangkan bahan untuk menulis esai. Peningkatan tampak pada kegiatan mahasiswa menemukan dan mengembangkan tesis, masalah, dan solusi dalam karangannya.

Tahap mengorganisasi karangan dilakukan melalui tiga kegiatan, yaitu mengelompokkan masalah utama, menyusun kerangka karangan, dan mengurutkan masalah-masalah pendukung. Peningkatan kemampuan mahasiswa mengorganisasi karangan dapat terwujud karena dosen dan mahasiswa mengikuti prosedur pelaksanakan tindakan sesuai dengan rancangan pembelajaran yang telah disusun. Peningkatan kemampuan mengorganisasi masalah tanpak pada kegiatan mahasiswa menyusun kerangka karangan. Mahasiswa mampu mengelompokkan masalahmasalah utama, mengurutkan masalah pendukung, dan menyusun kerangka karangan.

Tahap pengembangan tulisan dilakukan melalui dua kegiatan, yaitu mengembangkan tulisan dengan bahasa yang efektif dan menyunting karangan. Peningkatan kemampuan mengembangkan karangan dapat terwujud karena dosen dan mahasiswa mengikuti prosedur pelaksanakan tindakan sesuai dengan rancangan pembelajaran yang telah disusun. Mahasiswa mampu mengembangkan karangan berdasarkan kerangka karangan yang telah disusun. Peningkatan tampak pada kemampuan mahasiswa menuangkan tesis, masalahmasalah, dan solusi.

\section{UCAPAN TERIMA KASIH}

Artikel ini di angkat dari laporan hasil penelitian yang dibiayai oleh dana Anggaran DIPA UNY tahun 2011 alokasi FBS. Oleh karena itu, ucapan terima kasih disampaikan kepada BPP penelitian FBS UNY yang telah mendanai dan menyelenggarakan seminar hasil penelitian. Selanjutnya, ucapan terima kasih disampaikan kepada dua reviewer anonim yang telah membaca, mengoreksi, dan memberi masukan terhadap artikel ini.

\section{DAFTAR PUSTAKA}

Arends, Richard I. 2008. Learning To Teach (Belajar untuk Mengajar). Yogyakarta: Pustaka Pelajar.

Arikunto, Suharsimi. 2008. Penelitian Tindakan Kelas. Jakarta: Bumi Aksara.

Boardman Chintya A. dan Jia Fridenberg. 2008. Writing To Communicate (Paragraphs and Essays). New York: Carlise Publishing.

Brown, H. Douglas. 2008. Teaching by Priciples An Interactive Approach to Language Pedagogy. New York: Wesley Longman.

Challagam, Michael dan Joan Rotheri. 1993. Teaching Factual Writing. Erskineville: MEDSP.

Haines, Chatherine. 2004. Assessing Students Written Work (Marking Essays and Reports). London: RoutlegeFalmer.

Hedge, Tricia. 2008. Teaching and Learning in the Language Classroom. Oxford University Press.

Hiland, Kent. 2003. Second Language Writing. Cambidge: Cambridge University Press. 
Nilson, Linda B. 2010. Teaching At Its Best (A Research Based Resource For College Instructors). San Francisco: Wiley Inprint.

Nurgiyantoro, Burhan. 2001. Penilaian dalam Pengajaran Bahasa dan Sastra. Yogyakarta: BPFE-Yogyakarta.

Nurhadi. 2009. Bagaimana Menulis: Handbook Of Writing (Modul Perkuliahan). Program Pascasarjana Universitas Negeri Malang.

Olson, Carol Booth. 1992. Thinking Writing: Fostering Critical Thinking Through Writing. California: Harper Collins Publishers.

Oxford, Rebecca L. 1990. Language Learning Strategi: What Every Should Know. Boston: Heinly Publisher.

Suparno dan Muhammad Yunus. 2003. Keterampilan Dasar Menulis (Modul) Universitas Terbuka. Jakarta: Universitas Terbuka.
Tomskins, Gail E. dan Hoskisson Kenneth. 1991. Language Art Content and Teaching Strategies. Boston: Macmillan Publising.

Tomkins, Gail E. 2010. Literacy For the 21st Century a Balanced Approach. Boston: Allyn and Bacon.

Wahab, Abdul. 1999. Menulis Karya Ilmiah. Surabaya: Airlangga University Press.

Watkins, Peter Knapp Wegan. 2005. Genre, Text, and Grammar: Technologies for Teaching and Assessing Writing. Australia: Everbest Printing.

White, Fred D. 1986. The Writer's Art a Practical Rethoric and Handbook. New York: Wadsword Publishing Company.

Wibowo, Wahyu. 2007. Menjadi Penulis dan Penyunting Sukses. Jakarta: Bumi Aksara. 